\title{
Long-term oral refeeding of patients with cirrhosis of the liver
}

\author{
BY KLAUS NIELSEN ${ }^{1}$, JENS KONDRUP ${ }^{1}$, LARS MARTINSEN ${ }^{1}$, \\ HENRIK DØSSING ${ }^{1}$, BENNY LARSSON ${ }^{2}$, BIRGITTE STILLING ${ }^{1}$ \\ AND METTE GOTTLIEB JENSEN ${ }^{1}$ \\ ${ }^{1}$ Clinical Nutrition Unit and Division of Hepatology, Department of Medicine A-2152 \\ and ${ }^{2}$ Department of Medicine TTA-2001, Rigshospitalet, 9 Blegdamsvej, DK-2100 Ø, \\ Copenhagen, Denmark
}

(Received I July 1994 - Revised 5 January 1995 - Accepted 30 January 1995)

\begin{abstract}
A previous study has shown that maInourished, clinically stable patients with liver cirrhosis are in protein and energy balance at their spontaneous dietary intake and that an improvement in nutritional status cannot be anticipated at this intake (Nielsen et al. 1993). In the present study we examined to what extent oral intake could be increased by nutritional support, and to what extent dietary protein would be retained with increased intake. The techniques used for balance studies were also validated since this information is not available for patients with liver cirrhosis. Fifteen malnourished patients with alcoholic liver cirrhosis were given increasing amounts of a balanced ordinary diet for 38 (SE 3 ) d. Intakes of protein and energy were recorded by weighing servings and leftovers on food trays. Protein intake was calculated from food tables. Total $\mathbf{N}$ disposal was calculated after measurement of urinary $\mathbf{N}$ excretion, and protein balance was calculated from the $\mathbf{N}$ balance. $A$ validation study of protein balance in a subgroup of patients (analysis of $\mathbf{N}$ in food by the duplicate portion technique, correction for incomplete recovery of urine by measurement of urinary para-aminobenzoic acid (PABA) after administration of PABA tablets, and measurement of faecal $N$ ) did not change protein balance values. Protein intake increased from 1.0 (SE 0.1 ) $\mathrm{g} / \mathrm{kg}$ per d to 1.8 (SE 0.1$) \mathrm{g} / \mathrm{kg}$ per d. With increasing protein intake, 84 (SE 8$) \%$ of the increase in intake was retained. The rate of protein retention was not saturated at the intakes obtained in this study. Protein intolerance was only encountered in one patient. Available evidence indicates that the requirement for achieving $\mathbf{N}$ balance is increased in these patients but protein retention is highly efficient with increased intake. Protein retention is dependent on energy balance. Energy intake was calculated from food tables and total energy expenditure was calculated by the factorial method. A validation study was performed in a subgroup of patients. The energy contents of food sampled by the duplicate portion technique, and of urine and faeces were measured by bomb calorimetry. Resting energy expenditure (REE) was measured by indirect calorimetry before and at the end of the study, and $\mathrm{O}_{2}$ uptake during bicycle exercise was measured before and at the end of the study. The measured intake of metabolizable energy was on average $13 \%$ lower than the value given in food tables. Calculated energy expenditure was not changed by the validation study. Mean energy intake was 163 (SE 10) $\mathrm{kJ} / \mathrm{kg}$ per d and mean energy expenditure was 134 (SE 5$) \mathrm{kJ} / \mathrm{kg}$ per $\mathrm{d}(P=0.007)$, indicating that the protein retention described occurred at a positive energy balance. It is concluded that a substantial retention of dietary protein can be obtained by oral nutrition support over a prolonged period of time in patients with liver cirrhosis. Requirements of protein for maintenance and repletion in these patients are discussed.
\end{abstract}

Oral refeeding: Nitrogen retention: Protein requirement: Energy balance: Alcoholic cirrhosis

The poor nutritional status of many patients with alcoholic liver cirrhosis may be caused by a number of nutritional and metabolic abnormalities (McCullough \& Tavill, 1991; Kondrup et al. 1992). We reported previously that malnourished patients with liver cirrhosis were in protein and energy balance at their spontaneous dietary intake, even 
though the clinical condition was stable after the event that led to admission to the hospital (Nielsen et al. 1993). In contrast to what might be expected for malnourished individuals, these patients do not increase their dietary intake to the extent that a significant improvement in nutritional status can be anticipated. In the present study we examined to what extent the oral intake of the patients could be increased over an extended period of time, and to what extent this would be associated with protein retention.

In our previous study protein balance occurred at a protein intake of $0.83 \mathrm{~g} / \mathrm{kg}$ per d (Nielsen et al. 1993). In malnourished patients without organ disease, protein balance occurs at an intake of about $0.5 \mathrm{~g} / \mathrm{kg}$ per d (Barac-Nieto et al. 1979). The increased protein required to achieve protein balance in patients with liver cirrhosis indicates that protein retention is decreased. In the present study we examined whether protein retention associated with increased protein intake is also decreased. In addition, we examined energy intake and expenditure in order to ascertain that the patients were in positive energy balance.

\section{METHODS}

\section{Patients}

Malnourished patients were recruited from the department of hepatology when the cause of their admission to hospital had been treated and they were otherwise considered eligible for discharge from hospital in the near future. It was considered that their nutritional status could probably be improved by a gradual increase in dietary intake, consisting of meals prepared in the kitchen associated with the department. All subjects had biopsy-proven alcoholic cirrhosis. Patients with hepatic encephalopathy, positive results for hepatitis $\mathrm{B}_{\mathrm{s}} \mathrm{Ag}$, overt diarrhoea, renal disease, diabetes mellitus, fever, or malignant diseases were not included. Nutritional status was evaluated as described previously (Nielsen et al. 1993). The patients were considered to be malnourished if one or both of the following criteria were met: body weight $<80 \%$ of reference weight, or lean body mass ( $72 \mathrm{~h}$ creatinine excretion) $<80 \%$ of reference value. The clinical status of the patients was classified according to the Child-Pugh score (Pugh et al. 1973). The patients were included in the programme when the ability to cooperate had been verified during the initial screening procedure (see below). The patients were instructed that the study period was intended to last for at least 4 weeks but the length of the study period was finally determined by the patients. Of a total of twenty-four patients initially included in the study, seven patients decided to leave the hospital within 2 weeks due to loss of motivation, mostly associated with a further improvement in clinical status. These patients were excluded from further analysis. One patient was transferred to the surgical department for liver transplantation and one patient was excluded from analysis when it turned out that the patient had a colon tumour.

\section{Refeeding protocol}

As a screening procedure, nutritional status (including three $24 \mathrm{~h}$ collections of urine) and spontaneous intake of the hospital diet were registered for $3 \mathrm{~d}$, as described previously (Nielsen et al. 1993). Patients suspected of not complying with collection of urine or registration of dietary intake were not included in the study. After the screening period the food was prepared in the kitchen associated with the department. All food items and leftovers were weighed. In the first period of $4 \mathrm{~d}$ the energy and protein intakes were maintained at the registered pre-study intake, allowing a validation of the balance obtained in the screening period. Due to the presumed risk of provoking encephalopathy, the protein intake was increased gradually by increasing dietary intake by $15-20 \%$ in subsequent periods of 4-6 d. The rate of increase in dietary intake was variable since it was adjusted to each patient's eating capacity. The energy composition of diets with respect to protein, 
carbohydrate and fat was fixed at the composition recorded during the screening procedure, since we did not have a rationale for changing the composition of the diet in any specific way. $\mathrm{Na}$ and water were restricted in patients with ascites and oedema. In other respects the diets were customary mixed daily diets, prepared as far as possible according to the desires of the patients. Signs of encephalopathy were evaluated daily and reaction time was measured weekly (Elsass et al. 1985). The patients stayed in the department throughout the study, under metabolic ward conditions. A few patients were allowed to spend one or two weekends at home during the study period. These patients were supplied with prepacked food from the kitchen and they brought back leftovers and urine collections.

\section{Analytical methods}

Routine laboratory tests were performed using standard methods. As a quantitative measure of liver function, galactose elimination capacity was determined according to Tygstrup (1966).

Nitrogen balance. Protein intake was calculated from weighed dietary intake by means of food tables. $\mathrm{N}$ excretion was measured in $24 \mathrm{~h}$ urine collections during the whole study by a micro Kjeldahl technique (Keltec Systems, Tecator AB, Hoganaes, Sweden). Faecal and skin $\mathrm{N}$ losses were taken to be proportional to protein intake (Bingham \& Cummings, 1985). In their study, faecal (13\%) and skin (4\%) $N$ losses accounted for $17 \%$ of dietary intake (at an intake of about $100 \mathrm{~g}$ protein/day). In the present study the mean protein intake was about $90 \mathrm{~g} / \mathrm{d}$. The mean faecal and skin $\mathrm{N}$ losses were therefore taken to be $(90 \times 0 \cdot 17 / 6 \cdot 25)=2.5 \mathrm{~g} \mathrm{~N} / \mathrm{d}$. Protein balance was then calculated as:

$$
\text { protein balance }=\text { protein intake }-(6.25 \times(24 \mathrm{~h} \text { urinary } \mathrm{N}+2 \cdot 5)) \text {. }
$$

A correction for loss of urine was performed in the last seven patients by giving paraaminobenzoic acid (PABA) tablets as described by Bingham \& Cummings (1983). Four, rather than three, doses of $80 \mathrm{mg} / \mathrm{d}$ were given (one tablet with each large meal and one tablet at bedtime) to allow for the short elimination time of PABA (Bingham \& Cummings, 1983). Recovery of PABA in $24 \mathrm{~h}$ urine collections was measured during the whole study period. Days with a recovery of less than $90 \%$ of the PABA were excluded and, instead, the average of the $\mathrm{N}$ excretions on the days before and after was used as $\mathrm{N}$ excretion on the missing day (Bingham \& Cummings, 1985). As a validation study in the last five patients, $\mathrm{N}$ was also measured in duplicate portions of food, and in faeces, in three periods during the study. Each period lasted $3 \mathrm{~d}$ and the periods chosen were at the beginning, middle and end of the study.

Energy balance. Energy intake was calculated from weighed dietary intake by means of food tables. Energy expenditure (for maintenance) was calculated by the factorial method, as described previously (Nielsen et al. 1993). Calculated BMR (Harris \& Benedict, 1919) was multiplied by a $24 \mathrm{~h}$ average activity factor calculated from partial activity factors derived from the patient's recording of physical activity. The number of hours per $\mathrm{d}$ spent on each activity was divided by $24 \mathrm{~h}$ and multiplied by a specific activity factor. These partial activity factors were summed to give the $24 \mathrm{~h}$ average. Sleeping, lying awake in bed, sitting, walking and training were given specific activity factors of $0 \cdot 9,1 \cdot 2,1 \cdot 3,2.5$ and $7 \cdot 0$ respectively. The specific activity factors are multiples of resting energy expenditure (REE) associated with a specific physical activity.

As a validation study, the calculated BMR was compared with measured REE before and at the end of the study in the last eight patients. REE was measured by indirect calorimetry according to Weir (1949). The measurement was performed after an overnight fast while the patient was still in the supine position. Expired air was collected in three Douglas bags over a period of 6-8 min each. $\mathrm{O}_{2}$ analysis was performed on an $\mathrm{O}_{2}$ analyser 
(Servomex OA 189; Servomex, Crowborough, Sussex) and $\mathrm{CO}_{2}$ on a Carpnograph Godart 146 (Godart, De Bilt, The Netherlands) (Ingemann-Hansen et al. 1980).

A specific activity factor was validated in the last five patients. The increase in energy expenditure was measured during bicycle exercise before and at the end of the study. The patients were exercised for $7 \mathrm{~min}$ at $60 \mathrm{~W}$ and air was collected in a Douglas bag during the last $2 \mathrm{~min}$. Energy balance was further validated in these patients by measuring the energy content of duplicate portions of food, and of faeces and urine, by bomb calorimetry (Southgate \& Durnin, 1970) in the same three periods as described for protein.

Anthropometrics. Triceps skinfold (TSF) and mid-arm circumference were measured as the mean of triplicate determinations twice weekly by one observer $(\mathrm{KN})$, using Harpenden skin callipers. Mid-arm muscle area (MAMA) was calculated and expressed as a percentage of the expected value for age and sex. Initial and final values include the average of the first and last weeks' set of measurements. Initial and final lean body mass (LBM) values were calculated from three $24 \mathrm{~h}$ urinary creatinine collections. Urinary creatinine excretion was also measured daily throughout the study. Further details of these procedures have been given previously (Nielsen et al. 1993).

\section{Statistics}

Results are expressed as means with their standard errors. Measurements were related to recorded body weight at the time of measurement. Comparisons between groups of data were made using Student's $t$ test for paired data. Linear regression analysis was performed by the least squares method.

\section{Ethics}

The study was approved by the local Ethics Committee and conducted in accordance with the principles for human experimentation as defined in the Declaration of Helsinki II.

\section{RESULTS}

Refeeding was begun at a mean of 19 (SE 3; range 7-42) d after admission when the patients had reached a stable clinical condition, and immediately after the screening procedure. The initial clinical and nutritional indices are shown in Table 1. Body weight was unreliable as a measure of nutritional status because of ascites in nine patients.

The patients were refed for a mean of 38 (range 24-63) d (Table 2). Five patients completed $\geqslant 3$ weeks but less than 5 weeks and ten patients completed $\geqslant 5$ weeks. The variability of study period was due to the patients' variable motivation for continuing the study. The initial and final energy percentages for protein, carbohydrate and fat were 11.6 (SE 1.1) and 12.3 (SE 1.0), 55.2 (SE 3.3) and 54.8 (SE 3.7), 33.2 (SE 2.4) and 32.9 (SE 2.8) respectively. Three patients had to be supplemented with energy in the form of maltodextrines towards the end of the study in order to keep the volume of diet manageable. One patient experienced a significant increase in reaction time when the protein intake was increased from 80 to $95 \mathrm{~g}$ daily. Protein intake was then lowered to $80 \mathrm{~g}$ for the rest of the study period and the reaction time returned to normal. No other patients showed signs of encephalopathy.

\section{Protein retention}

Recovery of PABA was measured to correct for loss of urine. In the seven patients examined (study period: 37 (SE 2) d), cumulative $\mathrm{N}$ excretion with all days included was 94 (SE 3) \% of the value (339 (SE 43) g N) obtained with the PABA correction, i.e. omitting days with $<90 \%$ recovery of PABA (see p. 559).

In the last five patients protein balance was validated more completely. As calculated 
Table 1. Clinical and nutritional status of fifteen patients with liver cirrhosis before refeeding

(Mean values with their standard errors)

\begin{tabular}{|c|c|c|c|}
\hline & $n$ & Mean & $\mathrm{SE}$ \\
\hline Female/male & $5 / 10$ & & \\
\hline Child-Pugh groups A/B / $C^{*}$ & $2 / 10 / 3$ & & \\
\hline Age (years) & & 50 & 3 \\
\hline Height (m) & & $1 \cdot 70$ & 0.02 \\
\hline Weight $\uparrow(\mathrm{kg})$ & & $57 \cdot 8$ & $2 \cdot 2$ \\
\hline Weight (\% of reference) & & 87 & 2 \\
\hline Lean body mass ( $72 \mathrm{~h}$ creatinine) ( $\mathrm{kg})$ & & $30 \cdot 1$ & $1 \cdot 2$ \\
\hline Lean body mass ( $\%$ reference) & & 63 & 3 \\
\hline Triceps skinfold $(\mathrm{cm})$ & & 0.74 & 0.06 \\
\hline Triceps skinfold (\% reference) & & 50 & 5 \\
\hline Mid-arm-muscle area $\left(\mathrm{cm}^{2}\right)$ & & $38 \cdot 7$ & $2 \cdot 3$ \\
\hline Mid-arm-muscle area ( $\%$ reference) & & 70 & 3 \\
\hline
\end{tabular}

* Patients with liver cirrhosis are commonly stratified according to a clinical index comprising the severity of encephalopathy, ascites, icterus, reduction in plasma albumin and prolongation of prothrombin time.

$\dagger$ Nine patients with ascites.

Table 2. Protein intake and nitrogen balance in fifteen patients with liver cirrhosis during refeeding*

(Mean values with their standard errors)

\begin{tabular}{lcc}
\hline \hline & Mean & SE \\
\hline & 38 & 3 \\
& & \\
Duration (d) & & \\
Protein intake (g/kg per d) & 0.98 & 0.08 \\
$\quad$ Initial & 1.78 & 0.11 \\
$\quad$ Final & 1.47 & 0.09 \\
$\quad$ Average & 0.46 & 0.06 \\
\hline Nitrogen balance (g protein $/ \mathrm{kg}$ per d) & & \\
\hline \hline
\end{tabular}

* For details of procedures, see pp. 558-559.

from measured contents of $\mathrm{N}$ in food, urine (including the PABA correction) and faeces, protein balance was $0.50(\mathrm{SE} 0.17) \mathrm{g} / \mathrm{kg}$ per $\mathrm{d}$ while when calculated from food tables and measured urinary $\mathrm{N}$ excretion (equation (1)) protein balance was 0.52 (SE $0 \cdot 17$ ) $\mathrm{g} / \mathrm{kg}$ per d. These results are the means of three periods each of $3 \mathrm{~d}$ duration in each patient (see p. 559). The increase in plasma urea (see Table 5) represents an increase in $\mathrm{N}$ equal to approximately $2 \mathrm{mg}$ protein $/ \mathrm{kg}$ per $\mathrm{d}$.

Fig. 1 shows the weekly averages of cumulative protein balance in the ten patients who completed $\geqslant 5$ weeks of the study. For comparison, the changes of indices used to describe initial nutritional status are shown. Weight increased at similar rates in patients with and without ascites.

Table 2 shows that protein intake almost doubled and that protein retention was one third of the average intake. The increases in anthropometric values, for all fifteen patients during the total study period were: body weight, 3.4 (SE 1.0) $\mathrm{kg}(P<0.005)$; LBM (72 h creatinine), 2.4 (SE 0.6) $\mathrm{kg}(P<0.005)$; MAMA, 3.1 (SE 0.5) $\mathrm{cm}^{2}(P<0.001)$; and TSF, 0.7 (SE 0.3) $\mathrm{mm}(P<0.05)$. 

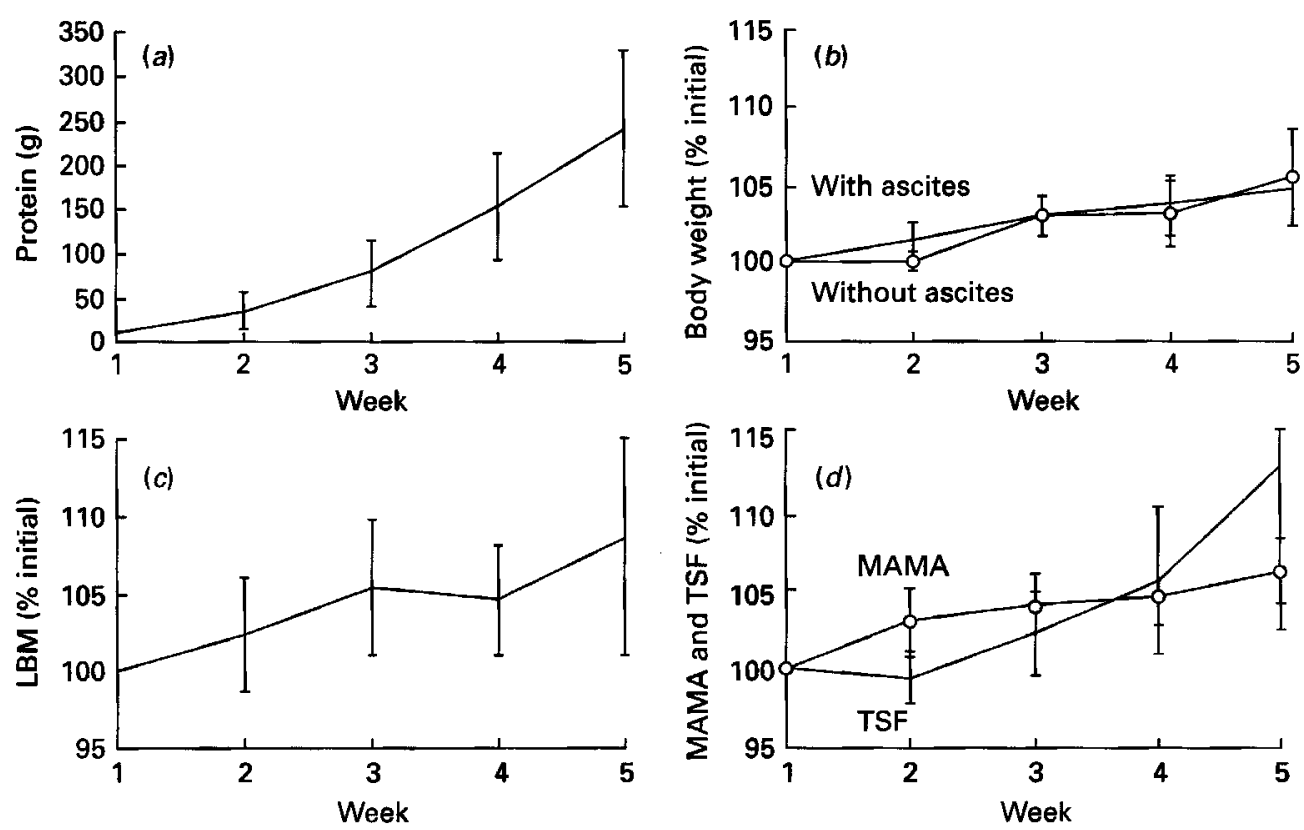

Fig. 1. Changes in nutritional variables with time in ten patients with liver cirrhosis who completed $\geqslant 5$ weeks refeeding. (a) Retention of protein, calculated by equation (1) (see p. 559); (b) change in body weight expressed as a percentage of initial body weight (four patients without ascites, six patients with ascites); (c) change in lean body mass (LBM) determined from $24 \mathrm{~h}$ creatinine excretion, expressed as a percentage of initial LBM; (d) changes in triceps skinfold (TSF) and mid-arm-muscle area (MAMA) expressed as a percentage of initial values. Values are means with their standard errors indicated by vertical bars.

Table 3. Protein retention with increased intake (slopes of linear regression analysis) and protein intake at nitrogen balance (intercepts with zero balance, see $p .562$ ) in fifteen patients with liver cirrhosis during refeeding

(Mean values with their standard errors)

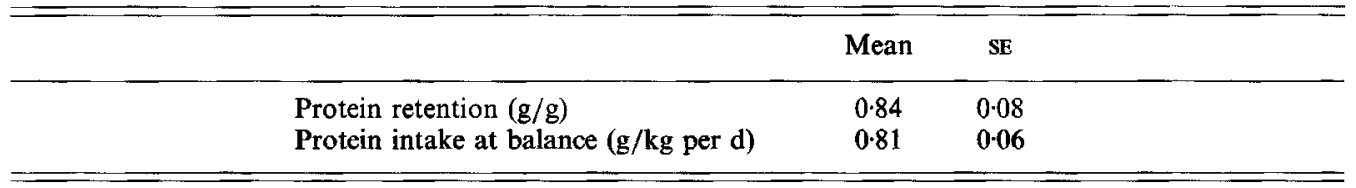

Protein retention as a function of protein intake in individual patients was subjected to linear regression analysis. The consecutive averages of $3 \mathrm{~d}$ periods of intake and balance were used as data pairs for this analysis. The analysis (Table 3) indicated that the average slope, equal to increase in protein retention relative to increase in protein intake, was close to unity (results not shown: $r^{2} 0.89$ (SE 0.03 ); $n 15$ ) and the analysis allowed a calculation of the mean intercept of the abscissa, corresponding to protein intake at protein balance.

\section{Energy balance}

In the five patients examined, the measured energy content of food was 184 (SE 17) $\mathrm{kJ} / \mathrm{kg}$ per $d$, and energy contents of faeces and urine were 11 (SE 3) and 7 (SE 1) kJ/kg per d respectively. The measured intake of metabolizable energy (167 (SE 14) kJ/kg per d) was 
Table 4. Energy balance during refeeding ( $k J / k g$ per $d)$ in fifteen patients with liver cirrhosis*

(Mean values with their standard errors)

\begin{tabular}{lll}
\hline & Mean & SE \\
\hline Energy intake & & \\
$\quad$ Initial & 123 & 10 \\
Final & 190 & 11 \\
Average & $163^{\mathrm{a}}$ & 10 \\
Activity factor & 1.30 & 0.03 \\
Maintenance energy expenditure & $134^{\mathrm{b}}$ & 5 \\
\hline
\end{tabular}

a,b Mean values not unlike superscript letters were significantly different $(P=0.007)$.

* For details of procedures, see pp. 558-560.

Table 5. Clinical chemical variables measured in patients with liver cirrhosis before and after refeeding

(Mean values with their standard errors for fifteen subjects)

\begin{tabular}{|c|c|c|c|c|c|}
\hline \multirow[b]{2}{*}{ Variable } & \multirow{2}{*}{$\begin{array}{l}\text { Reference } \\
\text { value }\end{array}$} & \multicolumn{2}{|c|}{ Initial } & \multicolumn{2}{|c|}{$\begin{array}{c}\text { Final } \\
(\% \text { initial })\end{array}$} \\
\hline & & Mean & SE & Mean & SE \\
\hline Haemoglobin (mmol/l) & $7 \cdot 0-11 \cdot 0$ & $6 \cdot 89$ & 0.22 & 103 & 4 \\
\hline Transferrin $(\mu \mathrm{mol} / \mathrm{l})$ & $31-57$ & 33 & 4 & $122 * *$ & 8 \\
\hline Albumin $(\mu \mathrm{mol} / \mathrm{l})$ & $550-830$ & $446 \cdot 1$ & $21 \cdot 7$ & 111 & 7 \\
\hline Prothrombin index & $0 \cdot 70-1 \cdot 30$ & 0.64 & 0.07 & 103 & 3 \\
\hline Alanine aminotransferase (EC 2.6.1.2) $(\mu \mathrm{kat} / \mathrm{l})$ & $0.17-0.67$ & 0.52 & $0 \cdot 10$ & 125 & 21 \\
\hline Alkaline phosphatase $(E C 3.1 .3 .1)(\mu \mathrm{kat} / \mathrm{l})$ & $1 \cdot 33-4 \cdot 58$ & 5.91 & 0.57 & $80^{* * *}$ & 6 \\
\hline Bilirubin $(\mu \mathrm{mol} / 1)$ & $4-17$ & $35 \cdot 1$ & $6 \cdot 2$ & 86 & 12 \\
\hline Galactose elimination capacity ( $\mathrm{mmol} / \mathrm{min}$ ) & - & $1 \cdot 27$ & 0.06 & $114^{*}$ & 6 \\
\hline $\mathrm{IgG}(\mu \mathrm{mol} / \mathrm{l})$ & $36-89$ & 142 & 15 & 98 & 5 \\
\hline IgA $(\mu \mathrm{mol} / \mathrm{I})$ & $3 \cdot 8-21 \cdot 0$ & $65 \cdot 2$ & $9 \cdot 5$ & $87^{*}$ & 8 \\
\hline $\mathrm{IgM}(\mu \mathrm{mol} / \mathrm{l})$ & $0 \cdot 3-3 \cdot 7$ & $4 \cdot 3$ & 0.6 & $80^{*}$ & 8 \\
\hline Ammonia $(\mu \mathrm{mol} / \mathrm{l})$ & $11-31$ & $53 \cdot 5$ & $5 \cdot 4$ & 87 & 20 \\
\hline Urea $(\mathrm{mmol} / \mathrm{l})$ & $2 \cdot 5-7 \cdot 5$ & $2 \cdot 7$ & 0.4 & $127^{*}$ & 8 \\
\hline
\end{tabular}

Mean value was significantly different from the initial value: ${ }^{*} P<0.05,{ }^{* *} P<0.02, * * * P<0.005$ (statistics performed on absolute differences).

$13 \%$ lower than the value obtained from food tables (192 (SE 20) $\mathrm{kJ} / \mathrm{kg}$ per d). Energy intake according to food tables was therefore corrected by this factor $(13 \%)$ in all fifteen patients (Table 4). In the eight patients examined, REE was close to predicted values and did not change during the study (initial 101 (SE 3) $\mathrm{kJ} / \mathrm{kg}$ per d, final 101 (SE 4) $\mathrm{kJ} / \mathrm{kg}$ per d being, respectively, 100 (SE 3)\% and 104 (SE 3)\% of calculated values). In the five patients examined, the increases in $\mathrm{O}_{2}$ uptake associated with $60 \mathrm{~W}$ bicycle exercise were 738 (SE 26) $\mathrm{ml} / \mathrm{min}$ and 737 (SE 49) $\mathrm{ml} / \mathrm{min}$ at the beginning and end of the study respectively, and were similar to those of matched control subjects (see p. 564).

Table 4 shows energy intake and energy expenditure required for maintenance. The mean of average activity factors during the study is also given in the Table. Intake was significantly larger than expenditure. 


\section{Other observations}

Table 5 shows the changes in clinical chemical variables. Initial values are shown as absolute values and final values are shown as a percentage of the initial value. Increased liver function was suggested by a significant increase in galactose elimination capacity and decreases in alkaline phosphatase $(E C$ 3.1.3.1) activity, immunoglobulin $\mathrm{A}(\mathrm{IgA})$ and IgM. Increases in albumin and transferrin indicate improvement in liver function or nutritional status, or both. A number of variables did not change significantly and are not shown (platelet count, leucocyte count, erythrocyte pteroylglutamate (folate), ionized $\mathrm{Ca}, \mathrm{Mg}$, phosphate, $\mathrm{Zn}$, vitamin $\mathrm{A}, \beta$-carotene, 25-hydroxycholecalciferol and 1,25-dihydroxycholecalciferol).

\section{DISCUSSION}

The nutritional status of the patients (Table 1) corresponds to a clinical evaluation ranging from slight to moderate malnutrition (Nielsen et al. 1993). The patients had a moderate degree of liver disease (Tables 1 and 5). They were all ambulatory and without overt signs of encephalopathy.

\section{Validation of nitrogen and energy balance measurements}

The correction for loss of urine (omission of days with $<90 \%$ recovery of PABA) did not change $\mathrm{N}$ excretion significantly, indicating that loss of urine was negligible in these selected patients. Protein balance, as determined by equation 1 , agreed within $4 \%$ with the more rigorous estimate in the last five patients, indicating that the results obtained by equation 1 are essentially correct. (In all fifteen patients, urinary $\mathbf{N}$ excretion was also calculated from $24 \mathrm{~h}$ urea excretion by multiplying urea-N by $1 \cdot 25$, as in the previous study (Nielsen et al. 1993). Calculated urinary $\mathrm{N}$ excretion was 102 (SE 2) \% of the measured value (361 (SE 41 ) $\mathrm{g} \mathrm{N}$ ), suggesting that measurement of $24 \mathrm{~h}$ urea is a satisfactory method also during repletion, e.g. for clinical purposes.) $\mathrm{N}$ accumulation in body urea was negligible.

The measured metabolizable energy content of food was $13 \%$ lower than that given in food tables. The energy contents of urine and faeces in our patients were similar to those previously reported in healthy subjects on a mixed diet containing fruit, vegetables and wholemeal bread (Southgate \& Durnin, 1970). The measured content of energy in food was expected to be the sum of the tabulated value and energy in faeces and urine, i.e. $192+11+7=210 \mathrm{~kJ} / \mathrm{kg}$ per $\mathrm{d}$, as opposed to $184 \mathrm{~kJ} / \mathrm{kg}$ per $\mathrm{d}$ actually measured. The discrepancy may be due to the fact that values in food tables are means from different suppliers while values for foods from this hospital's supplier may differ from the mean.

The agreement between calculated BMR and measured REE is similar to that in earlier reports in cirrhosis patients (Shanbhogue et al. 1987; Schneeweiss et al. 1990; Müller et al. 1991, 1994) and REE did not change during refeeding when related to body weight. We have previously found that the $60 \mathrm{~W}$ exercise-induced increase in $\mathrm{O}_{2}$ uptake in patients with liver cirrhosis is similar to that observed in healthy control subjects matched with respect to age, sex and body weight (745 (SE 50) $\mathrm{ml} / \mathrm{min}$; Martinsen et al. 1990), supporting the idea that the specific activity factors used for calculation of energy expenditure are applicable to these patients. The exercise-induced increase in $\mathrm{O}_{2}$ uptake did not change during refeeding. These findings indicate that the maintenance energy expenditure presented in Table 4 is essentially correct.

\section{Protein intake and nitrogen balance}

In malnourished patients it is not feasible to employ the usual procedure (World Health Organization, 1985) for determination of protein intake required for $\mathrm{N}$ balance. This procedure involves experimental introduction of a negative $\mathrm{N}$ balance and a long period of 
fixed neutral energy balance. Estimations of protein requirement for balance have to rely on available evidence in such patients.

Swart et al. (1989) examined eight patients with liver cirrhosis who had been on a protein-restricted diet for several months due to previous episodes of portosystemic encephalopathy. The patients were given three different amounts of protein $(40,60$ or $80 \mathrm{~g})$ in consecutive periods. Energy intake was kept constant. All patients were in negative $\mathrm{N}$ balance in the first period with the low intake but in positive $\mathrm{N}$ balance at the higher intakes. From linear regression analysis, a protein requirement of $0.75 \mathrm{~g} / \mathrm{kg}$ per $\mathrm{d}$ was calculated. When adding $2 \mathrm{SD}$ they reached a recommended intake of $1.2 \mathrm{~g}$ protein $/ \mathrm{kg}$ per $\mathrm{d}$. In their study the $\mathrm{N}$ content of food was not measured and the possibility of loss of urine was not considered. Energy intake (about $120 \mathrm{~kJ} / \mathrm{kg}$ per d) may have been marginally deficient, at least compared with the calculated energy expenditure of our patients (Table 4), and in their study there was no attempt to evaluate energy balance. In the study of Nielsen et al. (1993) linear regression analysis of the correlation between spontaneous protein intake and protein balance in thirty-seven patients with liver cirrhosis suggested that protein requirement for protein balance was $0.83 \mathrm{~g} / \mathrm{kg}$ per $\mathrm{d}$. All patients were in positive balance at a protein intake above $1.2 \mathrm{~g} / \mathrm{kg}$ per $\mathrm{d}$. In the present study linear regression analysis suggested that protein balance would be zero at an intake of $0.81 \mathrm{~g} / \mathrm{kg}$ per d (Table 3). Adding 2 SD would lead to a recommended intake of $1.3 \mathrm{~g} / \mathrm{kg}$ per d. Six of the fifteen patients were examined only at a positive balance, and energy intake was increased concomitantly with the increased protein intake. However, both violations of the usual procedure for estimating protein requirement would lead to an underestimation of protein requirement. The present study therefore adds to the available evidence that protein requirement for protein balance is increased in patients with liver cirrhosis. In particular, the present study suggests that this is also the case when energy balance is strongly positive.

Swart et al. (1988) suggested that the increased protein requirement is due to reduced glycogen stores, leading to a high rate of early postabsorptive gluconeogenesis from tissue proteins. Unpublished results from the present study showed that the initial plasma concentrations of insulin-like growth factor 1 (IGF-1) and insulin-like growth factor 1 binding protein-3 (IGFBP-3) were about $25 \%$ of control values and did not rise during the 6 weeks refeeding. This could also contribute to the increased protein requirement for maintenance.

\section{Protein retention at excess intake}

Protein retention was very efficient with increasing intake ( $84 \%$, see Table 3 ) and showed a linear relationship with intake also at initial levels of intake below protein balance in the nine patients who were in negative balance at the beginning (results not shown). This indicates that the increased requirement for protein to achieve protein balance is a 'threshold' phenomenon (a parallel shift to the right of the retention curve) rather than a generally decreased utilization of dietary protein. The pattern of amino acids required for maintenance of body protein is different from the pattern required for deposition of new protein (Reeds \& Hutchens, 1994). In patients with cirrhosis the requirement for amino acids limiting maintenance may be elevated while the requirement for amino acids limiting deposition of new protein is not. With one exception, there was no saturation of protein retention at the intakes obtained in the present study, suggesting that protein requirement in terms of maximum rate of protein retention is higher than the levels of intake obtained in this study.

In underweight patients without organ disease, the effect of long-term oral refeeding on protein retention has been examined in three studies (Barac-Nieto et al. 1979; Russell et al. 1983; Forbes et al. 1984), with a total of thirty-one patients (nineteen males, twelve 
females). As an average of these studies, subjects with a LBM ( $24 \mathrm{~h}$ creatinine) reduced to $59 \%$ of the reference value given $220 \mathrm{~kJ} / \mathrm{kg}$ per $\mathrm{d}$ and $2.0 \mathrm{~g}$ protein $/ \mathrm{kg}$ per $\mathrm{d}$ for 4-6 weeks retained $0.7 \mathrm{~g}$ protein $/ \mathrm{kg}$ initial body weight per $\mathrm{d}$. Our patients (having a similar initial reduction in LBM) retained a slightly lower amount of dietary protein at slightly lower average protein and energy intakes. Protein retention with increased intake seems to be nearly as efficient in cirrhotic patients as in underweight patients without organ disease. The higher intake required for zero protein balance in patients with cirrhosis is of little quantitative importance at high levels of intake.

Body composition was not measured since we considered determination of LBM and fat mass (FM) e.g. by isotopically labelled water, ${ }^{40} \mathrm{~K}$ counting or bioelectrical impedance to be dubious in patients with a pathological and variable accumulation of fluid and electrolytes. Increases in LBM and FM were, however, suggested by the increases in MAMA, LBM ( $72 \mathrm{~h}$ creatinine) and TSF. The protein retention (Table 2) can be recalculated to a formation of $2.2 \mathrm{~g} \mathrm{LBM} / \mathrm{kg}$ per d at an expense of energy of $17 \mathrm{~kJ} / \mathrm{kg}$ per d (Forbes, 1987). According to Table 4 there would still be energy available for formation of FM.

\section{Nutritional therapy}

The present study agrees with the observation from controlled trials of oral supplements, or tube feeding, that malnourished patients with liver cirrhosis in general tolerate increasing amounts of protein intake without developing encephalopathy (Bunout et al. 1989; Cabre et al. 1990; Kearns et al. 1992). The protein retention, and the improvement in liver function, is compatible with the positive effect of nutritional therapy on clinical outcome, or short time survival, reported in several randomized controlled studies of more severely ill patients with liver cirrhosis (Cerra et al. 1985; Diehl et al. 1985; Naveau et al. 1986; Bunout et al. 1989; Cabre et al. 1990; Mezey et al. 1991; Kearns et al. 1992; review by Kondrup et al. 1992).

The present study indicates that nutritional therapy by means of food is feasible in clinically stable patients over a long period of time. In an ongoing study of similar patients we have reached a mean dietary protein intake of about $2 \mathrm{~g} / \mathrm{kg}$ per d within 2 weeks (also in a diet with about $12 \%$ energy as protein), with the same efficiency of protein retention as in the present study. This indicates that substantial repletion can also be achieved rapidly in these patients.

This study was supported by the Danish Medical Research Council (grant no. 12-8112). The skilful technical assistance of Lise Lotte Hansen is gratefully acknowledged.

\section{REFERENCES}

Barac-Nieto, M., Spurr, G. B., Lotero, H., Maksud, M. G. \& Dahners, H. W. (1979). Body composition during nutritional repletion of severely undernourished men. American Journal of Clinical Nutrition 32, 981-991.

Bingham, S. \& Cummings, J. H. (1983). The use of 4-aminobenzoic acid as a marker to validate the completeness of $24 \mathrm{~h}$ urine collection in man. Clinical Science 64, 629-635.

Bingham, S. \& Cummings, J. H. (1985). Urine nitrogen as an independent validatory measure of dietary intake: a study of nitrogen balance in individuals consuming their normal diet. American Journal of Clinical Nutrition 42, 1276-1289.

Bunout, D., Aicardi, V., Hirsch, S., Petermann, M., Kelly, M., Silva, G., Garay, P., Ugarte, G. \& Iturriaga, H. (1989). Nutritional support in hospitalized patients with alcoholic liver disease. European Journal of Clinical Nutrition 43, 615-621.

Cabre, E., Gonzalez-Huix, F., Abad-Lacruz, A., Esteve, M., Acero, D., Fernandez-Banares, F., Xiol, X. \& Gassull, M. A. (1990). Effect of total enteral nutrition on the short-term outcome of severely malnourished cirrhotics. Gastroenterology 98, 715-720.

Cerra, F. B., Cheung, N. K., Fischer, J. E., Kaplowitz, N., Schiff, E. R. \& Dienstag, J. L. (1985). Disease-specific amino acid infusion (F080) in hepatic encephalopathy: a prospective, randomized, double-blind, controlled trial. Journal of Parenteral and Enteral Nutrition 9, 288-295. 
Diehl, A. M., Boitnott, J. K., Herlong, H. F., Potter, J., Van Duyn, M. A., Chandler, E. \& Mezey, E. (1985). Effect of parenteral amino acid supplementation in alcoholic hepatitis. Hepatology 5, 57-63.

Elsass, P., Christensen, S.-E., Mortensen, E. L. \& Vilstrup, H. (1985). Discrimination between organic and hepatic encephalopathy by means of continuous reaction times. Liver 5, 29-34.

Forbes, G. B. (1987). Human Body Composition. Growth, Aging, Nutrition, and Activity. New York: SpringerVerlag.

Forbes, G. B., Kreipe, R. E., Lipinski, B. A. \& Hodgman, C. H. (1984). Body composition changes during recovery from anorexia nervosa: comparison of two dietary regimes. American Journal of Clinical Nutrition 40 , 1137-1145.

Harris, J. A. \& Benedict, F. G. (1919). A Biometric Study of Basal Metabolism in Man. Carnegie Institute of Washington Publication no. 279, p. 227. Washington, DC: Carnegie Institute.

Ingemann-Hansen, T., Bundgaard, A., Halkjær-Kristensen, J., Siggard-Andersen, J. \& Wecke, B. (1980). Maximal oxygen consumption rates in patients with bronchial asthma - the effect of $\beta_{2}$-adrenoreceptor stimulation. Scandinavian Journal of Clinical and Laboratory Investigation 40, 99-104.

Kearns, P. J., Young, H., Garcia, G., Blaschke, T., O'Hanlon, G., Rinki, M., Sucher, K. \& Gregory, P. (1992). Accelerated improvement of alcoholic liver disease with enteral nutrition. Gastroenterology 102, $200-205$.

Kondrup, J., Nielsen, K. \& Hamberg, O. (1992). Nutritional therapy in patients with liver cirrhosis. European Journal of Clinical Nutrition 46, 239-246.

McCullough, A. J. \& Tavill, A. S. (1991). Disordered energy and protein metabolism in liver disease. Seminars in Liver Disease 11, 265-277.

Martinsen, L., Kondrup, J., Larsson, B., Hansen, J. K., Døssing, H. \& Nielsen, K. (1990). Oxygen uptake and substrate flux during exercise in patients with liver cirrhosis. Clinical Nutrition 9, Suppl., 47 Abstr.

Mezey, E., Caballeria, J., Mitchell, M. C., Pares, A., Herlong, F. \& Rodes, J. (1991). Effect of parenteral amino acid supplementation on short-term and long-term outcomes in severe alcoholic hepatitis: a randomized controlled trial. Hepatology 14, 1090-1096.

Müller, M. J., Böker, K. H. W. \& Selberg, O. (1994). Review: Are patients with liver cirrhosis hypermetabolic? Clinical Nutrition 13, 131-144.

Müller, M. J., Fenk, A., Lautz, H. U., Selberg, O., Canzler, H., Balks, H. J., vz Muhlen, A., Schmidt, E. \& Schmidt, F. W. (1991). Energy expenditure and substrate metabolism in ethanol-induced liver cirrhosis. American Journal of Physiology 260, E338-E344.

Naveau, S., Pelletier, G., Poynard, T., Attali, P., Poitrine, A., Buffet, C., Etienne, J.-P. \& Chaput, J.-C. (1986). A randomized clinical trial of supplementary parenteral nutrition in jaundiced alcoholic cirrhotic patients. Hepatology 6, 270-274.

Nielsen, K., Kondrup, J., Martinsen, L., Stilling, B. \& Wikman, B. (1993). Nutritional assessment and adequacy of dietary intake in hospitalized patients with alcoholic liver cirrhosis. British Journal of Nutrition 69, 665-679.

Pugh, R. N. H., Murray-Lyon, I. M., Dawson, J. L., Pietroni, M. C. \& Williams, R. (1973). Transection of the oesophagus for bleeding oesophageal varices. British Journal of Surgery 60, 646649.

Reeds, P. J. \& Hutchens, T. W. (1994). Protein requirements: from nitrogen balance to functional impact. Journal of Nutrition 124, 1754S-1764S.

Russell, D. McR., Prendergast, P. J., Darby, P. L., Garfinkel, P. E., Whitwell, J. \& Jeejeebhoy, K. N. (1983). A comparison between muscle function and body composition in anorexia nervosa: the effect of refeeding. American Journal of Clinical Nutrition 38, 229-237.

Schneeweiss, B., Graninger, W., Ferenci, P., Eichinger, S., Grimm, G., Schneider, B., Laggner, A. N., Lenz, K. \& Kleinberger, G. (1990). Energy metabolism in patients with acute and chronic liver disease. Hepatology 11 , 387-393.

Shanbhogue, R. L. K., Bistrian, B. R., Jenkins, R. L., Jones, C., Benotti, P. \& Blackburn, G. L. (1987). Resting energy expenditure in patients with end-stage liver disease and in normal population. Journal of Parenteral and Enteral Nutrition 11, 305-308.

Southgate, D. A. T. \& Durnin, J. V. G. A. (1970). Calorie conversion factors. An experimental reassessment of the factors used in the calculation of the energy value of human diets. British Journal of Nutrition 24, $517-535$.

Swart, G. R., van den Berg, J. W. O., van Vuure, J. K., Rietveld, T., Wattimena, D. L. \& Frenkel, M. (1989). Minimum protein requirements in liver cirrhosis determined by nitrogen balance measurements at three levels of protein intake. Clinical Nutrition 8, 329-336.

Swart, G. R., van den Berg, J. W. O., Wattimena, J. L. D., Rietveld, T., van Vuure, J. K. \& Frenkel, M. (1988). Elevated protein requirements in cirrhosis of the liver investigated by whole body protein turnover studies. Clinical Science 75, 101-107.

Tygstrup, N. (1966). Determination of the hepatic elimination capacity (Lm) of galactose by single injection. Scandinavian Journal of Clinical and Laboratory Investigation 18, 118-125.

Weir, J. B. de V. (1949). New methods for calculating metabolic rate with special reference to protein metabolism. Journal of Physiology 109, 1-9.

World Health Organization (1985). Energy and Protein Requirements. Report of a Joint FAO/WHO/UNU Expert Consultation, pp. 52-68. Geneva: World Health Organization. 